\title{
Hubungan Kemampuan Berpikir Kritis dengan Kemampuan Menulis Teks Editorial Siswa Kelas XII
}

\author{
Tia Puspita Sari ${ }^{1}$, Dawud ${ }^{1}$, Kusubakti Andajani ${ }^{1}$ \\ ${ }^{1}$ Pendidikan Bahasa Indonesia-Universitas Negeri Malang
}

\begin{tabular}{|c|c|}
\hline INFO ARTIKEL & ABSTRAK \\
\hline Riwayat Artikel: & $\begin{array}{l}\text { Abstract: This research was conducted using quantitative methods. Data analysis of } \\
\text { this study was carried out using correlation techniques. The data collection process is }\end{array}$ \\
\hline Diterima: $30-11-2018$ & done using critical thinking test instruments and test instruments writing editorial texts. \\
\hline Disetujui: $18-01-2019$ & The relationship between variables was analyzed using Pearson Product Moment \\
\hline $\begin{array}{l}\text { Kata kunci: } \\
\text { critical thinking; } \\
\text { editorial text; }\end{array}$ & $\begin{array}{l}\text { and significant relationship between critical thinking skills and the ability to write } \\
\text { editorial texts at a significance level of } 0,000 \text {. That is, one of the determinants of the } \\
\text { success of writing editorial texts is that students must have high critical thinking skills. }\end{array}$ \\
\hline $\begin{array}{l}\text { argument; } \\
\text { berpikir kritis; } \\
\text { teks editorial; } \\
\text { argumen }\end{array}$ & $\begin{array}{l}\text { Abstrak: Penelitian ini dilakukan dengan menggunakan metode kuantitatif. Analisis } \\
\text { data penelitan ini dilakukan dengan menggunakan teknik korelasi. Adapun proses } \\
\text { pengambilan data dilakukan dengan menggunakan instrumen tes berpikir kritis dan } \\
\text { instrumen tes menulis teks editorial. Hubungan antar variabel dianalisis menggunakan } \\
\text { teknik analisis korelasi Pearson Product Moment. Hasil penelitian ini menunjukkan } \\
\text { bahwa terdapat hubungan positif dan signifikan antara kemampuan berpikir kritis dan } \\
\text { kemampuan menulis teks editorial pada taraf signifikansi 0,000. Artinya, salah satu } \\
\text { faktor penentu keberhasilan menulis teks editorial adalah siswa harus memiliki } \\
\text { kemampuan berpikir kritis yang tinggi. }\end{array}$ \\
\hline
\end{tabular}

\section{Alamat Korespondensi:}

Tia Puspita Sari

Pendidikan Bahasa Indonesia

Universitas Negeri Malang

Jalan Semarang 5 Malang 65145

E-mail: tiapuspita1@gmail.com

Kemampuan berpikir kritis adalah kemampuan seseorang untuk berpikir secara aktif, efektif dan logis, dapat berkembang, memiliki kepekaan terhadap sekitar, memberikan penilaian terhadap suatu hal dengan objektif. Seorang pemikir kritis selalu berusaha untuk hidup secara rasional dan empathically. Pemikir kritis menggunakan akal dan intelektual yang dimiliki untuk menganalisis, menilai, dan meningkatkan pemikiran terhadap setiap hal yang mereka temui. Mereka bekerja dengan tekun untuk mengembangkan kebajikan intelektual, integritas intelektual, kerendahan hati, kesopanan, empati, keadilan dan kepercayaan berdasarkan alasan.

Menurut (Paul \& Elder, 2006) seorang pemikir kritis mampu menulis sesuatu yang substantif. Pemikir kritis memahami pentingnya menulis untuk belajar. Pemikir kritis mampu secara jelas dan akurat mengemukakan dan mengevaluasi ide-ide mereka sendiri, maupun gagasan yang disampaikan orang lain. Pemikir kritis menggunakan tulisan sebagai alat penting untuk mengungkapkan ide-ide secara mendalam dan permanen. Selanjutnya, Forster menyatakan bahwa seseorang tidak dapat mengetahui apa yang mereka pikirkan, kecuali dengan menuliskan gagasan atau ide-ide yang dipikirkan (Hood, 2011). Penulis berpengalaman tahu bahwa tindakan menulis adalah stimulus untuk berpikir. Hal ini menunjukkan bahwa kemampuan berpikir kritis sangat penting dimiliki seseorang untuk mengembangkan kemampuan menulis.

Tarigan (2008) menyatakan bahwa keterampilan menulis sangat dibutuhkan, terutama dalam kehidupan modern ini. Hal ini karena dengan menulis seseorang dapat mengungkapkan gagasan yang dimiliki untuk kepentingan khalayak umum. Selain itu, sebuah tulisan juga dapat menggambarkan perkembangan ilmu pengetahuan dan kemajuan teknologi saat itu. Pendapat ini juga dikuatkan oleh Hartono (2002) bahwa berkomunikasi dengan bahasa tulis merupakan bagian dalam pemenuhan kebutuhan primer dalam kebudayaan dan peradaban modern.

Salah satu keterampilan menulis dapat diwujudkan melalui tulisan editorial. Menurut Rivers (2004) editorial adalah cara yang dilakukan oleh seseorang dalam menyajikan fakta dan opini untuk menafsirkan berita-berita penting dan bertujuan untuk memengaruhi pendapat umum berdasarkan sudut pandang suatu media. Salah satu unsur penting dari tulisan editorial adalah kehadiran fakta yang disertai opini penulis dalam menyikapi sebuah isu yang berkembang di masyarakat. 
Keakuratan fakta dan opini yang disajikan oleh penulis bergantung pada hubungan yang saling mendukung antara fakta yang ditemukan dengan opini penulis. Penyajian fakta dan opini dalam teks editorial tentu saja membutuhkan pemikiran kritis dari penulis. Hal ini karena tanpa berpikir kritis, penulis sulit untuk menilai keakuratan fakta yang didapatkan sehingga penulis pun tidak dapat merumuskan argurmen yang kuat.

Dalam artikel ini dibahas bagaimana hubungan kemampuan berpikir kritis dengan kemampuan menulis teks editorial siswa kelas XII SMA Negeri 3 Malang. Alasan yang melatarbelakangi kajian ini diambil berdasarkan hasil penelitian (Çavdar \& Doe, 2012) dengan judul Learning through Writing: Teaching Critical Thinking Skills in Writing Assignments. Hasil penelitian tersebut menunjukkan penggunaan tugas menulis sebagai strategi untuk mengajarkan berpikir kritis dapat tercapai.

Selanjutnya, penelitian (Ng, 2017) dengan judul Thinking on writing a Critical Essay. Berdasarkan hasil penelitian yang dilakukan, untuk menulis esai kritis, seseorang disarankan membaca dan memiliki referensi bacaan yang mendukung tulisannya. Cara tersebut dilakukan supaya penulis dapat merangkum hasil bacaan, merevieu bacaan, membandingkan dengan sumber bacaan lain, dan mengembangkan argumen yang relevan sesuai dengan kutipan yang diambil.

\section{METODE}

Penelitian berjudul Hubungan Kemampuan Berpikir Kritis dengan Kemampuan Menulis Teks Editorial ini menggunakan jenis penelitian kuantitatif. Penelitian kuantitatif dipilih karena datanya berupa angka dan pengolahan data menggunakan statistik. Analisis data penelitian menggunkan teknik korelasi. Penelitian ini dilakukan di SMAN 3 Malang. Peneliti mengambil sampel berdasarkan teknik acak berkelompok (Cluster Random Sampling), yaitu dengan membuat undian nama-nama kelas, dan dipilih secara random. Jumlah kelas yang diambil ada empat sehingga jumlah sampel penelitian adalah 111 siswa. Hasil sampel acak yang terpilih adalah kelas A-5, C-5, D-5, dan I-5. Jumlah sampel penelitian pada empat kelas tersebut adalah 38\% dari jumlah populasi penelitian. Sampel tersebut sudah lebih dari yang dipersyaratkan oleh Arikunto (2006), yaitu sebanyak $25 \%$ dari populasi.

Data penelitian ini dianalisis dalam lima tahapan analisis. Pertama, melakukan perhitungan skor kemampuan berpikir kritis dan kemampuan menulis teks editorial. Sebelum melakukan teknik analisis data menggunakan teknik analisis statistik, hasil tes dikoreksi terlebih dahulu menggunakan pedoman penilaian yang telah dibuat. Penskoran tersebut dilakukan berdasarkan rubrik penilaian yang telah ditentukan. Setelah menghitung total skor yang diperoleh, ditentukan rentangan skor yang menggambarkan kemampuan berikir kritis dan menulis teks editorial.

Kedua, melakukan uji normalitas. Uji normalitas dilakukan dengan melihat hasil nilai skewness dan kurtosis data yang diperoleh melalui statistik deskriptif. Ketiga, melakukan uji hipotesis. Pengujian hipotesis penelitian ini dilakukan menggunakan teknik analisis korelasional. Teknik analisis korelasional yang digunakan disesuaikan dengan normal tidaknya distribusi data. Jika distribusi data normal, maka digunakan analisis korelasi Product Moment. Sebaliknya, jika distribusi data tidak normal, maka digunakan teknik analisis korelasi Rank Spearman. Untuk mengetahui hipotesis yang diajukan diterima maka harus dilihat koefisien korelasi dan taraf signifikansi. Hipotesis diterima jika koefisien korelasi dan taraf signifikansi lebih kecil dari $0,05(\mathrm{p}<0,05)$.

Keempat, melakukan pemaknaan terhadap hasil uji hipotesis yang diperoleh. Pemaknaan dalam penelitian ini dilihat dari korelasi antara kemampuan berpikir kritis dan kemampuan menulis teks editorial. Kelima, eksplanasi. Dalam penelitian ini teori digunakan sebagai alat eksplanasi. Teori menentukan hubungan antara kemampuan berpikir kritis dan menulis teks editorial secara sistematis.

\section{HASIL}

Berdasarkan analisis statistik diperoleh koefisien kolerasi kemampuan berpikir kritis dengan kemampuan menulis teks editorial 0,855 ( $\mathrm{p}=0,00)$. Berdasarkan hasil analisis dapat dinyatakan, jika siswa memperoleh skor tinggi dalam berpikir kritis, maka juga memperoleh skor tinggi dalam menulis teks editorial. Sebaliknya, siswa yang memperoleh skor rendah dalam berpikir kritis memperoleh skor rendah pula dalam menulis teks editorial. Artinya, terdapat korelasi positif antara kemampuan berpikir kritis dengan kemampuan menulis teks editorial. Dengan demikian, hipotesis penelitian "ada hubungan positif dan signifikan antara kemampuan berpikir kritis dengan kemampuan menulis teks editorial diterima."

\section{PEMBAHASAN}

Hasil analisis penelitian ini menunjukkan terdapat hubungan positif yang signifikan antara kemampuan berpikir kritis dengan kemampuan menulis teks editorial. Artinya, siswa yang memiliki kemampuan berpikir kritis tinggi, juga memiliki kemampuan menulis teks editorial tinggi. Sebaliknya, siswa yang memiliki kemampuan berpikir kritis rendah, juga memiliki kemampuan menulis teks editorial rendah. 


\section{Hubungan Kemampuan Berpikir Kritis dengan Kemampuan Menulis Teks Editorial Berdasarkan Teori}

Berpikir kritis disebut juga rasional pikir. Kata 'rasional' berarti 'menggunakan alasan' untuk memecahkan setiap masalah. Seseorang mampu berpikir kritis harus melatih daya nalarnya. Menurut (Budden, 2007) ada tiga ciri seseorang telah mampu menggunakan penalaranya dengan baik, yaitu (1) memiliki alasan yang kuat, (2) mengevaluasi keyakinan dan tindakan diri sendiri, (3) mengungkapkan alasan-alasan kepada orang lain atas tindakan yang dilakukan. Dengan demikian, penting untuk memeriksa dasar keyakinan dan penalaran diri sendiri karena hal ini akan menjadi sudut pandang utama seseorang mulai untuk berpikir kritis.

Menurut (Elder \& Paul, 2012) berpikir kritis adalah cara berpikir untuk meningkatkan kualitas pemikirannya dengan terampil menganalisis, menilai, dan merekonstruksi sebuah persoalan. Disebut berpikir kritis jika seseorang memiliki sikap mandiri, disiplin diri, memonitor diri sendiri, dan melakukan penilaian dari setiap hal yang ditemui berdasarkan skemata yang telah dimiliki. Adapun menurut (Gray, 1990) berpikir kritis adalah keterampilan yang dapat ditingkatkan, seperti kecakapan lain, kemampuan seseorang untuk melaksanakannya akan meningkat jika dilakukan dengan praktik. Kuncinya adalah mengetahui apa dan mengapa hal tersebut harus dilatih.

Berdasarkan beberapa paparan teori di atas, dapat diketahui bahwa kemampuan berpikir kritis memiliki keterkaitan dengan kemampuan menulis teks editorial seseorang. Dalam hal ini, kemampuan menulis teks editorial merupakan kemampuan menulis yang bertujuan untuk mengulas sebuah persoalan dengan argumen-argumen penulis yang didukung fakta. Fakta yang dipilih untuk mendukung argumen telah dinilai keakuratan dan kredibilitasnya. Kemampuan seseorang dalam menilai fakta tersebut merupakan salah satu syarat kompetensi yang dimiliki oleh pemikir kritis seperti yang dikemukakan oleh Warnick \& Inch (1994) yang menyatakan bahwa untuk menyusun sebuah argumen yang kuat seseorang harus mampu mengevaluasi fakta atau bukti sebagai dasar argumen, menilai kredibilitas sumber, menilai keahlian sumber (jika menggunakan kutipan ahli), menilai objektivitas, konsistensi, relevansi, keakuratan, dan kebaruan data sebagai pendukung argumen. Semakin ahli seseorang dalam menilai bukti pendukung argumen, semakin kuat pula argumen yang dihasilkan. Hal ini dikarenakan bukti pendukung merupakan dasar sebuah argumen dibuat.

Pendapat Warnick dan Ich sesuai dengan pendapat (Facione, 1990), ada enam kecakapan berpikir kritis, yaitu menginterpretasi, menganalisis, mengevaluasi, menginferensi, menjelaskan, dan meregulasi diri. Menurut Glaser ada dua belas landasan berpikir kritis, meliputi (1) mengenal sebuah masalah yang ditemui, (2) menemukan solusi, saran, atau rekomendasi untuk suatu masalah, (3) mengumpulkan informasi pendukung argumen, (4) mengenal asumsi-asumsi, (5) menggunakan bahasa yang tepat dan jelas dalam mengungkapkan ide maupun pendapat, (6) menganalisis data yang ditemukan, (7) menilai keakuratan fakta dan mengevaluasi pernyataan orang lain, (8) mengenal hubungan yang logis antara masalah-masalah, (9) menarik simpulan, (10) menguji simpulan orang lain, (11) menyusun kembali pola keyakinan orang lain berdasarkan pengalaman yang lebih luas, dan (12) menilai sebuah peristiwa yang terjadi dalam kehidupan sehari-hari (Fisher, 2009).

Ciri lain yang perlu dimiliki seseorang pemikir kritis adalah elemen-elemen yang mendasari pola berpikir kritis dan bagaimana proses berpikir kritis. Menurut (Gray, 1990), ada empat elemen berpikir kritis, yaitu (1) berpikir aktif, (2) berpikir melibatkan kognitif, (3) berpikir kritis secara sadar, dan (4) berpikir kritis melibatkan perilaku. Ciri berpikir aktif adalah pemikir tidak hanya menerima informasi sebagaimana ditentukan oleh orang lain atau lingkungan di mana mereka menjadi bagian dari lingkungan tersebut. Berpikir aktif melibatkan kekritisan atas informasi yang didapatkan. Dalam hal ini seorang individu berusaha mengajukan pertanyaan dan menggunakan jawaban dari informan untuk mencari informasi lebih lanjut. Adapun, ciri berpikir kritis melibatkan kognitif adalah pemikir melibatkan logika dan kemampuan mengenali masalah. Selain itu, pemikir juga mencari tahu bagaimana solusi dari masalah dapat diselesaikan, memperoleh informasi yang paling berguna dan bermanfaat untuk memecahkan masalah, dan mengevaluasi efektivitas dari kedua proses pemikiran.

Ciri berpikir kritis dilakukan secara sadar adalah seseorang memahami sesuatu; untuk sengaja menerapkan seperangkat keterampilan dan kebiasaan untuk menertibkan serta menemukan struktur ide-ide dan informasi. Adapun ciri berpikir kritis melibatkan perilaku adalah seseorang mampu menarik kesimpulan secara logis; mengubah kesimpulan dalam tindakan logis. Seseorang yang benar-benar menunjukkan pemikiran kritis, baik pikiran dan tindakan perlu menyelaraskan hal tersebut dengan informasi yang tersedia.

Berdasarkan ciri-ciri seorang pemikir kritis yang telah dipaparkan dapat diketahui bahwa penulis yang mampu berpikir kritis akan mampu menggali persoalan lebih dalam dan mampu membuat solusi atas persoalan tersebut. Hal ini juga sesuai dengan kaidah menulis teks editorial, bahwa di dalam teks editorial harus dituliskan solusi atau rekomendasi untuk menyelesaikan persoalan yang diangkat. Berdasarkan teori yang telah dipaparkan dapat diketahui bahwa, kemampuan berpikir kritis memiliki hubungan dengan kemampuan menulis teks editorial. Seseorang yang berpikir kritis mampu menulis teks editorial, dengan tepat dalam menemukan masalah, menggali masalah lebih dalam agar mendapatkan data yang akurat, mengaitkan fakta dan argumen, menulis yang kuat dan tidak dapat ditangguhkan, serta menyusun teks editorial sesuai dengan kaidah penulisan. 


\section{Hubungan antara Kemampuan Berpikir Kritis dengan Kemampuan Menulis Teks Editorial Berdasarkan Hasil Penelitian Terdahulu}

Hasil penelitan ini dikuatkan oleh penelitian Suhartono (2014) yang menemukan bahwa kemampuan berpikir kritis berpengaruh langsung dengan kemampuan menulis karya ilmiah. Meskipun penelitian tersebut tidak fokus pada hubungan antara kemampuan berpikir kritis dan menulis teks editorial, tetapi hasil tersebut dapat dikaitkan dengan penelitian ini. Hal ini karena, penelitian tersebut memiliki fokus pada kemampuan yang sama, yaitu berpikir kritis dan menulis. Artinya, kemampuan berpikir kritis memiliki peran dalam menentukan kemampuan menulis seseorang.

Hasil penelitian ini juga dapat memperkuat hasil penelitian (Wade, 1995) dan (Klimova, 2011). Menurut (Wade, 1995), salah satu cara untuk mengembangkan keterampilan berpikir dapat dilakukan dengan mengembangkan kemampuan menulis. Hal tersebut juga sama dengan hasil penelitan (Klimova, 2011) yang mengungkapkan bahwa kegiatan menulis dapat membantu siswa mengembangkan keterampilan berpikir mereka secara aktif. Salah satu caranya adalah dengan memberikan tugas menulis argumentatif pada siswa. Siswa dituntut untuk menerapkan dan mengintegrasikan keterampilan berpikir mulai dari tingkat rendah hingga berpikir tingkat tinggi.

Berdasarkan paparan di atas dapat diketahui bahwa kemampuan menulis yang tinggi memerlukan kemampuan berpikir kritis yang tinggi. Hal ini karena seseorang yang ingin menulis, khususnya menulis teks editorial harus mampu mengkritisi kejadian-kejadian yang aktual, krusial, dan kontroversial yang terjadi di masyarakat. Teks editorial yang ditulis harus memiliki argumen-argumen yang kuat dengan fakta-fakta yang akurat dan berasal dari sumber yang kredibel. Seseorang yang ingin menulis teks editorial harus memiliki pemikiran yang luas, mampu menilai keakuratan fakta yang ditemukan, menilai keselarasan antara fakta dan argumen yang dibuat, serta mengevaluasi hasil tulisan tersebut. Kemampuan-kemampuan tersebut adalah ciri-ciri kompetensi yang dimiliki oleh pemikir kritis. Dengan demikian, hasil penelitian ini menunjukkan seseorang yang memiliki kemampuan berpikir kritis tinggi juga memiliki kemampuan menulis teks editorial tinggi.

\section{SIMPULAN}

Berdasarkan hasil penelitian dan pembahasan dapat disimpulkan bahwa terdapat hubungan positif dan signifikan antara kemampuan berpikir kritis dan kemampuan menulis teks editoral siswa kelas XII SMA. Hal ini menunjukkan bahwa siswa yang memiliki kemampuan berpikir kritis tinggi, juga memiliki kemampuan menulis teks editorial tinggi. Sebaliknya, siswa yang memiliki kemampuan berpikir kritis rendah, juga memiliki kemampuan menulis teks editorial rendah. Siswa yang telah memiliki kemampuan berpikir kritis tinggi akan lebih mudah menuangkan gagasan-gagasan yang dimilikinya dalam bahasa tulis. Dengan demikian, siswa akan lebih aktif dan produktif menghasilkan tulisan yang berkualitas.

Berdasarkan hasil penelitian dan pembahasan dapat dikemukakan saran-saran untuk pihak-pihak terkait. Pihak-pihak yang dimaksud, yaitu (1) pengajar bahasa Indonesia di sekolah menengah atas (2) dan peneliti lain. Pertama, bagi para guru di sekolah menengah atas, disarankan untuk memberikan pola pembelajaran yang dapat mengembangkan kemampuan berpikir kritis siswa dalam setiap pembelajaran, khususnya dalam pembelajaran menulis. Salah satu cara yang dapat dilakukan adalah menciptakan suasana yang kondusif dalam pembelajaran di kelas, yaitu dengan membiasakan siswa lebih tanggap terhadap suatu peristiwa, berani mengungkapkan gagasan yang dimiliki berdasarkan bukti, saling menghargai dan menghormati pendapat orang lain, mendorong siswa untuk berpikir luas, memberikan tes-tes yang mengharuskan siswa menggunakan kemampuan berpikir tingkat tinggi, serta membiasakan siswa untuk mempereoleh bukti yang kuat sebelum mempercayai sebuah informasi atau peristiwa. Kedua, bagi peneliti lain disarankan untuk menindaklanjuti penelitian ini dengan penelitian-penelitan lain. Tindak lanjut yang dimaksud adalah dengan mengembangkan dan menelaah faktor-faktor lain yang dapat berhubungan dengan kemampuan berpikir kritis dan menulis teks editorial.

\section{DAFTAR RUJUKAN}

Arikunto, S. (2006). Dasar-Dasar Evaluasi Pendidikan. Jakarta: Bumi Aksara.

Budden, L. (2007). Critical Thinking Skills. Developing Effective Analysis and Argument. In Contemporary Nurse (Vol. 25). https://doi.org/10.5172/conu.2007.25.1-2.174a

Çavdar, G., \& Doe, S. (2012). Learning through writing: Teaching critical thinking skills in writing assignments. PS - Political Science and Politics, 45(2), 298-306. https://doi.org/10.1017/S1049096511002137

Elder, L., \& Paul, R. (2012). Close Reading, Substantive Writing and Critical Thinking: Foundational Skills Essential to the Educated Mind. Gifted Education International, 25(3), 286-295. https://doi.org/10.1177/026142940902500310

Facione, P. A., Santa C. U., \& California S. U. (1990). Critical Thinking: A Statement of Expert Consensus for Purposes of Educational Assessment and Instruction Executive Summary "The Delphi Report." Research Findings and Recommendations Prepared for the Committee on Pre-College Philosophy of the American Philosophical Association, 423(c), 0-19. Retrieved from http://www.eric.ed.gov/ERICWebPortal/recordDetail?accno=ED315423

Fisher, A. (2004). Berpikir Kritis: Sebuah Pengantar. Terjemahan Benyamin Hadinata. 2009. Jakarta: Erlangga.

Gray, C. (1990). A Brief Guide to Thinking Critically. 1-4.

Hartono, B. (2002). Evaluasi Keterampilan Menulis. Makalah disajikan dalam Lokakarya Nasional Pengembangan Materi Membaca dan Menulis bagi Guru SLTP Tahun 2002, Semarang, Jawa Tengah, 15 s.d. 22 Oktober 2002. 
Hood, R. (2011). Writing to Think: Critical Thinking and the Writing Process “Writing is thinking on paper.”- William Zinsser. (December).

Klimova, B. F. (2011). Assessment methods in the course on academic writing. Procedia - Social and Behavioral Sciences, 15, 2604-2608. https://doi.org/10.1016/j.sbspro.2011.04.154

Ng, L. L. (2017). Thinking on writing a critical essay. Australasian Psychiatry, 25(2), 187-190. https://doi.org/10.1177/1039856217694958

Paul, R., \& Elder, L. (2006). Critical Thinking Reading \& Writing Test. Foundation for Critical Thinking. Retrieved from www.criticalthinking.org

Rivers, W. L. (2004). Media Massa dan Masayarakat Modern. Jakarta: Kencana.

Suhartono. (2014). Pengaruh Kebiasaan Membaca, Kemampuan Berpikir Kritis, dan Penguasaan Struktur Sintaksis terhadap Keterampilan Menulis Ilmiah. Lentera Pendidikan, 17(1), 36-6. https://doi.org/10.24252/lp.2014v17n1a4

Tarigan. H. G. 2008. Menulis sebagai Suatu Keterampilan Berbahasa. Bandung: Angkasa.

Wade, C. (1995). Using Writing to Develop and Assess Critical Thinking. Teaching of Psychology, 22(1), 24-28. https://doi.org/10.1207/s15328023top2201_8

Warnicks, B. \& Inch, E.S. (1994). Critical Thinking and Communication: The Use of Reason In Argument (Second Edition). New York: Macmillan Publishing Company. 